\title{
A place at the table: low wage workers and the bourgeois deal
}

\author{
JENNIFER BAKER \\ College of Charleston
}

Though it comes with its own burdens, a philosopher's task is lighter than that the economic historian sets before herself. Philosophers, after all, seek out the argument for 'markets' (plucking it out of any which source we please, shining it, propping it up with qualification after qualification, assessing it by just the light available). Deirdre McCloskey, in her magisterial trilogy, does much more than this. She develops arguments, too, of course (making the case for the bourgeois virtues, connecting material advances with equality), but this is done while she chronicles the views that have been maintained about markets for centuries. She also takes it upon herself to convince readers of (even) the fact of the Great Enrichment (work easily done in her hands, but still work). She is still just getting going. In Bourgeois equality: how ideas, not capital or institutions, enriched the world (2016), McCloskey not only holds up the Great Enrichment and deems it good, she argues that there is just one explanation of how it came about. Dimming the relevance of alternative explanations for the rise of capitalism (from Tocqueville to Weber to the multi-causal account of the modern day) is very heavy work. And yet? She does it, too, handily.

And how? She does not just wave at 'gains' from capitalism. You will not find her lingering at length on some description of a toaster or an iPhone (as if consumers are not already sold). She knows exactly what to emphasize so that her own thesis is put in the foreground: the preposterous magnitude of the Great Enrichment. It is not some mere "doubling or tripling of the material scope of human life" (p. 7). The world became (at least) 1500\% richer, and in a very short time, in places that had not been so different prior (p. 7). Other explanations only promise to account for how there came to be, say, a thirty-percent increase in entrepreneurs. Nothing like this is going to be able to account for change "by a factor of thirty" (p. 472). This is the bar which 
any causal explanation must reach. It is a brilliant set up: contending accounts can line up to be dismissed at a glance. Authors who fail to express astonishment over the humanitarian boon the Great Enrichment has been ("feel it on your pulse" [p. 7]) have simply not yet grasped the fact of it yet. The right explanation of the Great Enrichment, the "core model", must reckon with it being like a whole forest having suddenly gone up in flames (p. 473). ${ }^{1}$

And what would work as a global accelerant? It cannot be culture. Or technology. Or institutional change. Still less biology (p. 410). Plausibility requires that the Great Enrichment comes about through a mechanism that is quick, simple and certain. A nod of the head. A yes to a try. It is what she calls the "Bourgeois Deal" and it will be my focus in this response to her most recent book (p. 410).

To me, as a philosopher, it's a promising type of justification of a political system (I've called similar versions 'first-person justification' and I think the approach began with the Stoics). But I will not treat it as a (mere) philosophical device. She is, again, doing so much more. If the Bourgeois Deal (the "Deal") could not have happened (as she conceptualizes it), then the origins of our current system are going to be a murky matter and, perhaps, impossible to get past. Hers is the account that lets us look, instead, to what markets have brought us: according to the Bourgeois Deal, elites were given the chance to consider (as skeptically as they might, she of course chooses the word 'deal' to suggest all that it does) allowing the bourgeois their projects, on the understanding that the elites will be enriched by them. McCloskey puts the Deal in the mouths of the bourgeoisie: let us try out betterments in the market, we'll allow for "low-quality competitors" to rush in, driving down prices. Yes, we too might be enriched, in time. We know you don't like this, but don't worry, we've got very different habits than elites like you. There is nothing else involved other than letting us take this risk for ourselves. We'll even provide the start-up money. Yes, that is all. Your payoff is that you will become rich and be able to enjoy all these marvelous new things. (Imagine what the elites asked themselves: Is this all there is to it? How much money are we talking about again? So we

\footnotetext{
${ }^{1}$ McCloskey writes: "The core model, in other words, should not be nuclear fission, the reaching of a threshold-at which, with the creative people bouncing against each other, the reaction becomes self-sustaining. It was more like a forest fire. The kindling for a creative conflagration lay about for millennia, carefully prevented from burning by traditional societies and governing elites with watering cans. Then the historically unique rise of liberty and dignity for ordinary people disabled the watering cans and put the whole forest to the torch" (p. 473).
} 
will get much richer, and they do the work? I keep my social clubs? My estates? My esteem?)

McCloskey never means, of course, to deny that the Great Enrichment also had "legal, political, personal, gender, religious, philosophical, historical, linguistic, journalistic, literary, artistic, and accidental causes" (p. 410). She is looking for what we can say sparks the flame that burns so rapidly after 1848. It is quick, simple, and certain for those in power to merely say: Yes, you may keep that, you may try that. And as she puts it:

Thank God, then, for the Bourgeois Deal, and its democratic test by consumer satisfaction, and the private profit that so lucidly signals its success. And thank God too for the social gain from reasoning by commercial cost and benefit rather than by first-act equality or national glory or the interests of the aristoi or cute novelties in engineering or the number of souls entering heaven (p. 573).

The fire-hazard conditions of the Deal were the "accidental" distribution of "a novel liberty and dignity" that "was slowly extended to all commoners" (though this happened in Northwestern Europe, seeing how markets have taken off all over is her proof that it could have happened anywhere), which allowed the commoners to show off what they could do. ${ }^{2}$ Again, there was no psychological change, it was not religion that made the bourgeois so capable, and commoners had simply been held back in the past from furthering their own interests (having been given insufficient liberty and insufficient dignity). ${ }^{3}$ Tacking on anything else as strictly necessary to the transformation that was the Great Enrichment would slow down the speed (the efficacy) with which the Deal was taken.

Let me offer a quick list of implausible assumptions the Deal avoids.

\footnotetext{
2 As McCloskey says, "The psychological hypothesis one finds in Weber or in the psychologist David McClelland or in the historian David Landes does not stand up to the evidence, as for example the success of the overseas Chinese..." (p. 413).

${ }^{3}$ I have seen some interpretations of McCloskey's work suggest that she, bourgeois culture's number one fan, suggests that particular culture is also necessary to Great Enrichments, but I certainly read her as remaining "pluralistic" about the motivations of those who contribute to general affluence. Bourgeois values are very much suited to the market, and they are praiseworthy, and they help, but that is all. For example, McCloskey critiques Weber for trying to offer an over-tidy account of just two influences when it comes to bourgeois motivation. He is accused of using this over simplification as a way to be "charming" to readers (p. 273).
} 
1. It does not associate capitalism (a trade-tested system of betterment) with any particular culture or era.

2. It does not propose a new type of human.

3. It recognizes that the necessary political rights were in the hands of particular elites, and does not imagine some general consensus has emerged.

4. It does not substitute high praise for markets and bourgeois behavior for the idea that elites have made some kind of sacrifice in power.

5. It requires no sea change of feelings towards the bourgeois on behalf of elites, only bare tolerance of them.

6. It does not require elites to be interested in anything more than wealth for themselves.

7. It does not assume we engage each other philosophically, awaiting the presentation of air-tight arguments concerning our mutual welfare.

8. It does not suggest the needed "animating spirit" (or approving rhetoric) of trade-tested betterment is itself enough to bring about transformative economic change (p. 508).

9. It takes what is said to be "hidden" in very many verbal explanations of the market and suggests it is not. The elites could see what they would gain.

Much of Bourgeois Dignity is spent providing details to show why the Bourgeois Deal needed to be struck. Elites have long had scorn for the bourgeois, and McCloskey tracks its display and when there were signs that attitudes were beginning to change. But she is not neutral towards the ideologies of "the clerisy". From Aristotle, to the Stoics, to Shylock, to La bohème, McCloskey does not hold back in pointing out where views have got matters wrong. (I will never casually refer to my style as bohemian again). In doing this, she is treating their views as philosophical. She extracts the arguments instead of just pointing to their influence. And she warns us, at the end of the book, that we must continue to do what she has: supply "fresh persuasions" on behalf of the liberty and dignity of those who make us so well-off (p. 648).

Now, a rhetorician like McCloskey knows exactly what she is doing. With many arrows in her quiver, those she does not use have been left there for a reason. She does not shoot without a target audience, for goodness's sake. Since her prose is unmatched and her references

\footnotetext{
${ }^{4}$ For what it is worth, yes Aristotle is wholly mistaken about the role of profit, but he certainly takes some trade as crucial and necessary. The Stoics, I was sad to see, are taken as anti-commerce because of their ethical ideals, but they are (I argue elsewhere), due to their bi-level account of value, as pro-market as any view might be (Baker 2016).
} 
require a liberal arts education where one did the assigned reading, it is safe to assume she is aiming here to make the "clerisy" less confident (our anti-bourgeois and highly influential clergy, journalists, filmmakers, politicians, novelists and professoriate) and to embolden, also, her bourgeois readers (she at one point refers to us as bourgeoisie because we are reading).

But my question concerns a third audience: low wage earners living in affluent societies. What is their relationship with the Bourgeois Deal? ${ }^{5}$ I can see two options.

1) Low wage workers are simply at the table on the side of the bourgeois when the Deal is struck, hoping for the same liberty and dignity and betterment. Whether they become low wage workers in one of the more affluent societies is of no relevance. Their consent to "trade-tested betterment" is clear because the poor were already doing as much as they could to better their own situation (just as they would do later in functioning markets). And even if we question how supportive low wage workers have been or need to be, McCloskey settles the issue as follows: the Bourgeois Deal does not "require" the "exploitation of workers" (p. 583). In either case, the bourgeoisie need not be imagined striking a second deal with low wage workers, as low wage workers were not holding the bourgeoisie back. The elites were blocking trade tested betterment, so it was the elites with whom the Deal had to be struck.

2) The Bourgeois Deal is not negotiated with the past or present version of low wage workers, but if needed (if low wage workers begin to resist trade-tested betterment) a similar Deal could be drafted. It would require a) different terms or b) more explanation than is contained in the Deal proposed to the elites.

I would like to explore this last option. It dovetails with concerns about the rise of what Mark Blyth terms international "Trumpism". (If this movement amounts to a rejection of the Bourgeois Deal, that is quite a credit to the explanatory power of McCloskey's account.) But "Trumpism" is not identical to the perspective I want to consider. According to the data by Pew Research Council (2016), support for Trump seems to track feelings about President Obama more than it does income. I want to consider those whose wages are low in comparison to the affluence of their country more generally, to include those who want

${ }^{5}$ If today's low wage workers are simply considered bourgeoisie because they live in affluent societies, I would be surprised. I would argue that this is not how the lowwage workers I know and live with see themselves. 
nothing to do with a Trump. So, regardless of how we diagnosis the current political situation, are non-elite, non-clerisy, low wage workers satisfied with what they have already received in the aftermath of the Bourgeois Deal? One way to answer is by waiting to see. If low wage workers (in affluent societies) are interested in a) different terms, this will surely be worked out politically, with thousands of policy proposals on offer. So I would like to focus on b), the idea that a mutually satisfying Deal for low wage workers would differ from that which appealed to elites. And I would like to suggest that the bourgeoisie do need to address their low wage brethren, whether or not the bourgeoisie fear their power. Such an address requires explanations that have not been explicitly offered yet, both economic (what is hidden by markets and why) and, I want to suggest, ethical. ${ }^{6}$ Again, elites, in the McCloskey story of the Deal only need to be self-interested. As I will attempt to explain, I do not think the support of low wage workers can be got that directly. Of course an ethicist like me would see a role for ethical explanation, and I am happy to learn if McCloskey thinks it would be abandoning effective rhetoric to do what I suggest.

McCloskey already claims that low wage workers are victims of factual misunderstandings, having been led astray by anti-bourgeois rhetoric. Michael Sandel sings in the anti-bourgeois choir when he writes that Trumpists have

the sense that not only have jobs been lost through various trade agreements and technological developments, but the economic benefits associated with those agreements and those technologies have not gone to the middle class or to the working class but to those at the very top (Cowley 2016).

According to McCloskey, this particular "sense of injustice" (shared or not) is mistaken. ${ }^{7}$ Trade-tested betterment has actually given the working classes those preposterous changes in economic well-being. But, how, I wonder, would McCloskey both convince the working class of this, and make them care about it?

\footnotetext{
${ }^{6}$ As a practical matter, it would be simply intolerable to propose an ethical argument for markets to low wage workers without at the same time undertaking to do things such as decriminalize poverty. The list is longer, and my hope is that taking an explicitly ethical approach would highlight the urgency of criminal justice reform and the like.

${ }^{7}$ She does worry about corruption, of course, so she could swivel to find common ground there.
} 
Furthermore, read Sandel a bit longer and he brings up lost dignity. "What Trump really appeals to is the sense of much of the working class that not only has the economy left them behind, but the culture no longer respects work and labour" (Cowley, 2016). Is this also merely a mistaken impression? On their blogs, leading libertarians gleefully rip apart adjunct professors for wanting higher wages. Evidence of a terrible disdain for low wage work is as close as a google search. What would it take for McCloskey to agree with the "clerisy" that low wage workers have suffered grave losses of dignity in our current-day society? It is clear that McCloskey sees dignity as crucial. Even though she can be found, cleanly, neatly, suggesting that the only motivation that matters is the timeless one of wanting to better one's situation (it is certainly not greed that she needs to promote), she does not fail to recognize the role that extra-legal regard plays in the functioning of markets. McCloskey describes dignity as "the social honoring of all people", even after they've secured protection by rights (p. 403). Loss of dignity would seem to be a very legitimate concern. For these reasons, let me suggest some five modifications to the original Deal, so that it might appeal to low wage workers.

The first modification to the original Deal that I'd suggest: an explanation of both "what is hidden" by markets and why this is. Why risk ruining the elegance of the Deal as offered to elites? Elites could see themselves maintaining their status, clubs, and lifestyles with the added wealth. The vantage of low wage workers is not the same. To merely argue that the poor have been lifted out of unimaginable poverty is to fail to recognize this vantage. Aware that I am no skilled rhetorician, I would still like to (humbly) suggest that scare tactics is the wrong approach to securing low wage worker approval of our system. If the horrors of present-day Venezuela are used to convince low wage workers that the Deal we have is fair, it is still the case that low wage workers have less to lose in such a transition.

A second modification to the Deal I would suggest is some way of acknowledging the possibility of this: the working class (unlike the elites) are interested in more than the wealth they can expect to achieve after taking the Deal. So many defenses of the market are put in terms of compliments to the wonders of an iPhone and the like. Those addresses are made to only those who have purchasing power. Yes, our low wage workers have, thus far, been very supportive of the luxury 
items we generate. But how can praise of material items capture the reasons low wage earners participate in the market as they do?

As Tocqueville pointed out, by 'interest' we have never meant just those that are economic. Further, as Gordon Tullock (1985) pointed out, those society brands as non-cooperative (think of felons who cannot get rental agreements after serving their term) are prudent to defect. That was not determined on the basis of how much money is on the table. I can only imagine at what the realistic numbers are, when it comes to what low wage workers will gain through their cooperation (in comparison to what might be got if they 'negotiate'). But earning 20,000 dollars a year in our society is not so tempting that the issue is settled. To suggest that one's choice is either the current system or Venezuela strikes me as something skeptical Deal takers should not be expected to buy. So here is a third suggested modification to the Deal: praise for markets and bourgeois behavior cannot substitute for the idea that low wage earners might be asked to make some sacrifice in power.

I would like us to consider that low wage workers already have philosophical commitments, and that these may not be conducive to trade-tested systems of betterment. One example is ideas like: jobs are made secure only through political connections or jobs are property. ${ }^{8}$ Another example is inspired by Max Weber's description of the "spirit of capitalism" (2010 [1905], 9-10). The beliefs and values he associated with it are very familiar to me, a bourgeois person, and very unfamiliar to low wage earning friends. Weber, of course, suggested that the "spirit of capitalism" was a matter of non-believers being influenced by the non-religious content of ascetic Protestantism. Ben Franklin was not an ascetic Protestant, though he exemplified the influence of the ethos in his cheery bromides. The specific normative content in the "spirit of capitalism" as Weber describes it is not replaced in McCloskey's account. Yet I find it very plausible that Weber identified a set of beliefs that many of us still share. ${ }^{9}$ He talks of a suspicion of "spontaneous enjoyment of life" (159) and I recognize myself. He describes the idea

\footnotetext{
${ }^{8}$ At one point McCloskey tells us about a "peasant's" view of "exchange-always cheating, cheating, cheating." She describes the kind of "cheating magic of trade" that has "long angered people," as zero-sum is the "default in thinking about my gain and thine" (p. 434). But then, a line or two later, she points out that markets were not in fact beneficial to "peasants" until about 1800. It left me wondering whether a peasant's view should have been considered anything other than accurate. In other words, is a "peasant's view" of markets a realistic one (for the time) or not?

"I had trouble making sense of the idea that Weber was describing "individual ethics" rather than what is "honored or dishonored by society" (p. 118). Where would the overlap begin and end?
} 
that we have a duty to our possessions, to the extent that we are obedient stewards to them, and I think of the weekly ritual of washing of the nice vehicles (169). The condemnation of dishonesty and "unbridled greed" (170) are part of the ethos, too. That is nearly all toddlers hear from us. Work is considered admirable no matter what level at which it is done, and as a way to improve ourselves, or sort of set ourselves right internally. Isn't this why so many of us, no matter how many hours we put in at the office, find no excuse to keep an untidy home? And finally, that "the unequal distribution of the goods of this world" is considered to be efficacious for reasons mere humans cannot access is a very particular viewpoint, particularly supportive of trade-tested betterment.

Not all of us believe these things. It is not easy for me to see that this bundled ethos is shared by low wage workers in the US. I cannot guess as to what is cause and what is effect, but that is not my interest. Weber's "spirit of capitalism" is a way to think, philosophically (enough), about why differences in outcomes are justified in a capitalist system and why one is worth participating in. Those who do not share this particular "spirit" are left to justify the system without the same doxastic resources. McCloskey's argument, again, nicely avoided any dependence on some "deep" and heavy cultural justification of markets (one of many advantages over the old Weberian account) (p. 509). Yet, she also grants that bourgeois values are not introduced into vacuums; they may exist contemporaneous to non-elite anti-bourgeois commitments. I do not see that McCloskey has yet confronted a nonelite, non-bourgeois ethos as if it had normative content at odds with the terms of the original Deal.

For example, if a person identifies with celebrations rather than work, what kind of offer appeals to them? Add a lack of personal identification with one's home or possessions or even career (the bourgeoisie may have trouble believing it, but plenty of people are in this position). Then tack on the observation that those with the skill sets to do well in business are (though maybe honest and prudent) a bit wily ("daddy's boys" is an expression I've heard). Imagine seeing one's work as personally salubrious, but being fully aware that it serves as a punchline for the wealthier. Finally, be assured that the world is wicked and corrupt. You now have an outlook very unlike that of Poor Richard. How do the benefits of trade-tested betterment fair, when thrown into this mix (or any one like it)? 
I am not sure. I do not know how McCloskey would write for this audience. I am not even suggesting that low wage workers will not recognize what counts as general betterment. It may be we still all agree there. But I do think, if we imagine low wage workers at the table, we cannot fail to reckon with the role any non-bourgeois values play in how other values (including general betterment) are assessed. Non-bourgeois values amount to a rather intact philosophical outlook, and I think this could function as an "inner obstacle" to seeing the Deal as the bourgeois and (wealth-hungry) elites do (Gerth and Mills 1958, 58).

How to get around this? This is the boldest of my claims, a fourth modification to create a viable Deal with low wage workers: engage with them philosophically. Not over personal values or way of life, but over the issues of our mutual welfare and what we owe others. We were able to avoid this with the elites who deigned to tolerate the bourgeoisie (of course there may have been ethical motivations behind the granting of liberty and dignity, but the final assent to markets was a matter of selfinterest). But when we are certain that some market participants will not be living the life we laud as bourgeois, ordered and well-provisioned, why not appeal to them as philosophers? This is better than ignoring them. And my suggestion avoids trying to recommend bourgeois virtues to the uninterested..$^{10}$ (I am glad McCloskey lauds these "virtues", but she too thinks they are not a fit for everyone nor (again) necessary for us to all share). ${ }^{11}$

The argument that is left to be made is that markets bring about the Great Enrichment (see McCloskey to get convinced of this as fact), and if you will tolerate the bourgeoisie and their projects, you are helping the worst-off in the world rise up out of dire poverty. This is not an appeal

\footnotetext{
${ }^{10}$ My brother-in-law grew up under communism and always wanted to leave. If anyone compliments the system he asks what they like about his grandfather being kept in solitary confinement for wanting to keep a tractor. But his family still says, perhaps in a bit of joking manner, that for his father communism was a good system, because he is 'lazy'. (I know the man, I wouldn't call him lazy! He has many qualities I admire, but he was content under the previous system.) Fits like this exist.

${ }^{11}$ I appreciate so much of what McCloskey puts forward, including the limits of the bourgeois virtues. McCloskey is clear that bourgeois values are not for everyone, nor are they as securely fashioned together as we'd find in a more philosophical (or teleological) approach to the virtues. She has ensured that I detect no rivalry between the traditional accounts of virtue (which require a commitment to reordering your goals) and her description of the bourgeoisie. One bit of realism is here: "We (bourgeoisie) grumble. Did I get the best deal I could? Has he made a fool of me? He's a vicious profiteer. Why doesn't he gracefully give me a gift? We don't feel so when we have, in Boulding's vocabulary, 'some integrative relationship' with the other person" (p. 431).
} 
to self-interest. It does, however, give us a way to think of the bourgeois 'haves' in a society. They are a kind of accident of the market (see how I remove the moral compliments, stay with me). Markets just work in this way: they reward those who are well-positioned in an extreme manner. But life remains a challenge, full of tragedy. What is gained is just material wealth but not all the joys of living or our reasons for being here. I of course would insert the ethical theory on which I work to back up this story, but those details can be replaced with others. The idea is to provide the details, sincerely, to have them vetted and checked, as justification for the system we have.

Weber insisted that traditional permissiveness towards an ethos of "take what you can" was "one of the strongest inner obstacles which the adaption of men to the conditions of an ordered-bourgeois capitalistic economy has encountered everywhere" (Gerth and Mills 1958, 58). Though McCloksey too notes a role in the struggle against traditionalism, she does not see the obstacles as "inner", that is to say, held in the form of supporting beliefs about what is right. Commitments to the old system, the disasters, are unendorsed, loose, or venal, disguising self-interest. What I am asking for is that we recognize that the economic roles we play constitute our very self-identity (Ross 2012). ${ }^{12}$ So, the final modification I would suggest to the original Deal: something like a change in direction of feeling is necessary. Low wage workers are already tolerant of and respect people in business, so the change is not similar to elites being asked to respect rights. But how to think about the 'haves' when you are a 'have not' is missing in McCloskey's approach.

Trade-tested betterment is a system that deserves ethical sanction, but I am seeking an argument that addresses low wage workers when it comes to what they think about their role. This would not be "sociological" in the sense McCloskey uses to describe the Bourgeois Deal. It is psychological (and philosophical). But since people (whether low wage workers or not, so Trump fans and beneficiaries of agriculture subsidies included) can resist trade-tested betterment no matter what we can show them about it, it seems to me it is time to leave the table

\footnotetext{
${ }^{12}$ Don Ross has extensively characterized the processes by which people learn, over the course of childhood and adolescent development, to construct narrative selves. One of the properties ourselves have is described as follows: "The dimensions along which their variance is culturally salient form the basis for a prevailing typology of personalities and linked aptitude sets that are normatively and statistically associated with types of economic occupations and social roles" $(2012,25)$.
} 
where we negotiate rights and turn to how grateful we are to everyone who plays their part in lifting others out of poverty. In other words, it is the indirect benefit to the very poorest that is really of unimpeachable, ethical, merit in our system, and the low wage earners are giving more directly here than the 'haves'. Let's say it. Or sing it, as McCloskey might.

\section{REFERENCES}

Baker, Jennifer. 2016. Economic good as indifferent: the Stoics' radical approach. In Economics and the virtues: building a new moral foundation, eds. Jennifer Baker and Mark D. White. New York: Oxford University Press.

Cowley, J. 2016. Michael Sandel: The energy of the brexiteers and Trump is born of the failure of elites. The New Statesman.

http://www.newstatesman.com/politics/uk/2016/06/michael-sandel-energybrexiteers-and-trump-born-failure-elites (accessed June 13, 2016).

Gerth, H. H., and Mills, C. Wright. 1958. From Max Weber: essays in sociology. New York: Oxford University Press.

McCloskey, Deirdre Nansen. 2016. Bourgeois equality: how ideas, not capital or institutions, enriched the world. Chicago: University of Chicago Press.

Pew Research Council. 2016. Warmer feelings about Trump among Republicans critical of immigration, growing diversity, Islam. http://www.pewresearch.org/facttank/2016/06/02/more-warmth-for-trump-among-gop-voters-concerned-byimmigrants-diversity/ft_16-05-27_warmtrump/ (accessed June 30, 2016).

Ross, Don. 2012. The evolution of individualistic norms. http://newprairiepress.org/cgi/viewcontent.cgi?article=1070\&context=biyclc (accessed June 8, 2016).

Tullock, Gordon. 1985. Adam Smith and the prisoner's dilemma. The Quarterly Journal of Economics, 100: 1073-1081.

Weber, Max. 2010 [1905]. The Protestant ethic and the spirit of capitalism, revised 1920 edition. Translated by Stephen Kalberg. New York: Oxford University Press.

Jennifer A. Baker is associate professor of philosophy at the College of Charleston. Baker's research interest is in virtue ethics, in particular its theoretical structure and application. She is at work applying contemporary behavioral science to the claims necessary to virtue ethics, as well as applying virtue ethics to issues such as policing, internet privacy, and sportsmanship. She has recently co-edited a collection of new essays for Oxford University Press titled Economics and the virtues: building a new moral foundation (2016). In this collection is her most recent attempt to defend the Stoic approach to economics. Other articles include, "Who's afraid of a final end? The role of practical rationality in contemporary accounts of virtue", "Virtue ethics and practical guidance", and "Virtue and behavior".

Contact e-mail: <bakerja@cofc.edu> 